Ivana Milinković, Ivana Kovačević, Dobrivoje Mihailović Faculty of Organizational Sciences, Belgrade University

UDC: 005.966-057.875 159.923.2.072

\title{
What Do Freshmen Want? Career Path Preferences Among Students
}

DOI: 10.7595/management.fon.2017.0006

\begin{abstract}
This study assessed the possible relation between life goal aspiration/orientation, department affiliation, gender and career path preferences. For this study we used data from 364 freshmen from the Faculty of Organizational Sciences (FOS), University of Belgrade, with the intention to find out what their aspirations and career plans are. Studying at the FOS gives them opportunity to become entrepreneurs, as well as managers, so we wanted to examine whether their general life aspirations are related to their desired career plans. While results indicate that there is no substantial link between career preferences and life aspirations in this specific point of their life, we found that gender and department of study may have some impact on the career preferences.
\end{abstract}

Key words: lifegoal aspiration, intrinsic goal contents, extrinsic goal contents, career path JEL Classification: I23, C80, C83, L26

\section{Introduction}

While the paper presented at the Symorg conference gives some insight into the idea how intrinsic motivation is connected to and very likely a base of the entrepreneurship tendencies, this paper goes further in exploring the relation between those two concepts. Some theoretical analogies given in the previously presented paper (Milinkovic et al., 2016) were corroborated with a qualitative analysis of the interviews from successful entrepreneurs and their motivation (goals and motives that guided them toward their success in the domain). In this paper, there is a shift of methodology as we try to find some quantitative evidence on entrepreneurship motivation and not remain on mere analogy and individual cases. However, the results obtained by quantitative research gave unexpected results and pointed to the difference in career plans between students in terms of intrinsic motivation as well as indicated that future research may give insights of a possibility to create entrepreneurs through the process of appropriate education.

\section{Research Problem}

According to researchers it still remains unclear what motivation factors influence entrepreneurial versus managerial goals (Culbertson et al., 2011). Several studies and authors underline that the key role in the development of entrepreneurship is that of the entrepreneurial education of young people, developing their entrepreneurial skills (Marques \& Albuquerque, 2012). In our educational practice the entrepreneurship spirit is not systematically encouraged and students are denied theoretical and practical knowledge in the domain. In the environment of this kind their motivation to start their own business after finishing faculty is questionable.

\subsection{Theoretical Considerations: Goal-setting and Self-determination Theory}

The Locke's goal setting theory predicts that people will channel their efforts towards accomplishing their goals and that there is a direct linear relationship between goal challenge, level of performance and effort involved. This relationship will stay positive as long as the person is committed to the goal, has the requisite ability to attain it and does not have conflicting goals (Locke \& Latham, 2006). 
Regarding this theory we can notice some differences in setting goals for managers and entrepreneurs. Many of them share some characteristics, but some differences do exist; when it comes to the basic traits of each and their goals, they are conceptually distinct (Malach-Pineset al., 2002). Definitions of managers focus primarily on their goals to manage people and oversee change through financial, marketing, and strategic planning (Bateman et al., 2002) and they are part of controlled work environment which diminishes their experiences of autonomy, competence, and relatedness. Entrepreneurial goals are aimed at innovation, growth, uniqueness and the creation of value through new ventures or services (Matlay, 2005) but also at individual satisfaction and opportunity to create a new environment, meet new people, build a team and create jobs.

On the other hand, there is a self-determination theory (SDT) which suggests that people are motivated by a need to grow and gain fulfillment and that their activities are directed towards personal development, life goals and aspirations (Deci \& Ryan, 2008). Authors who had studied the SDT have focused on the distinction between intrinsic goal contents and extrinsic goal contents (Kasser \& Ryan, 2001). Intrinsic goals directly satisfy innate psychological needs such as those for personal growth, emotional intimacy and community involvement (Kasser \& Ryan, 1996) or what SDT refers to as relatedness, competence and autonomy (Deci \& Ryan, 2000). Also, there are extrinsic goals which less directly satisfy the psychological needs such as those for financial success, image, and fame (Sheldon et al., 2004).

As it was found in the research of Petrovic et al. (2015), goals focused toward personal development and those of social value had different impact on the professional choice of young people. Nevertheless, they found that there were a link between goal importance and expectations to achieve them by choosing the appropriate faculty. For respondents in their research, personal goals were more emphasized compared to abstract social values. Nevertheless, all correlations, even those significant, were not strong due to the fact that the level of preference has a restricted level of variation. Our goals are differently articulated, more concrete and less defined by the value system of a person. They are categorized into intrinsic and extrinsic goals, from which some of them have social and others have highly internal connotation.

Through research among freshmen we wanted to determine which goals, intrinsic or extrinsic, are more frequent, as well as whether they affect their desired career development plan in managerial or entrepreneurial directions. For that purpose we use the questionnaire with 6 categories that explain the 2 factors: extrinsic motivation (wealth, fame, self-image) and intrinsic motivation (personal development, relationships and society). Because of managers'/entrepreneurs' life goals characteristics many authors make a connection between managers and extrinsic life values/aspiration/goals and between entrepreneurs and intrinsic life values/aspiration/goals. From that point we have started our research, with the intention to make a connection between freshmen's life goals, on the one hand, and life aspiration, on the other hand.

\subsection{Research Objectives}

The main question to consider is whether students of the first year of studying associate their life aspirations with concrete perception of their future career. Although the Faculty from which our respondents are recruited offers through its curriculum the possibility to get acquainted with the concept of entrepreneurship and to acquire required skills, we believe that in their freshmen years of studying they have only a vague notion of the concept and possible opportunities.

The main objective of the research was focused on considering whether there is a correlation between students' life goals and their preferences for future career.

In addition to the two differently oriented goals (intrinsic and extrinsic), there are, roughly, three different directions for future profession: managing in large companies, managing in medium and small companies and starting their own business guided by their own entrepreneurship idea. While the first career concept of employment considers being directed toward advancing in the organizational hierarchy and the "middle path" implies being partially accountable for some ideas in the firm, the entrepreneurship preference means being responsible not only for the process but also for the idea of the business in question.

The applied objective of this empirical research is inspired by the fact that there are some endeavors of making the possibilities for entrepreneurship as a future vocation be more transparent in the educational context. 


\subsection{Research Hypotheses}

In this paper, the implicit idea is to explore what has an impact on an individual's decision to develop entrepreneurial career; whether it is the direction of a person studying at University, gender or intrinsic/extrinsic life values/aspiration/goals. It is addressed in the first hypothesis that postulate that:

Hyp. 1. There is a difference in life goals between students with various career path plans: students with intrinsic life goal choose entrepreneurship career path plan more often than students with extrinsic life goal. This hypothesis is partially based on the theoretical explanation of the concept of intrinsic motives according to the Self-determination theory. Deci and Ryan (2008) defined the content of intrinsic goals believing that personal growth, meaningful relationships and community contributions might be seen as goals that bring direct fulfillment while satisfying the basic needs, opposite to the extrinsic aspirations such as wealth, social recognition and self-image. Many authors describe entrepreneurial motivation basis in this direction.

As some departments and specific subjects prepare students better for different challenges, there might be a tendency to enroll to the different departments with the idea that they offer more mobility toward actualizing the own entrepreneurship conceptions. Analyzing the statistical data about students starting their own business, we have found evidence that students with knowledge in information and communication technology more often chose the entrepreneurial career path. Also, it is possible that some personal preferences and life aspirations could determine the enrollment at the specific department (Petrovic et al., 2015).

So we assumed that:

\section{Hyp. 2. There are differences between students of ISIT and Management}

Hyp 2.1.: in desired career path: students of ISIT are more prone towards entrepreneurship than students of Management.

Hyp. 2.2. in life goals: students of ISIT are more prone towards intrinsic life goals in comparison with students of Management.

There has been a trend of starting a new business in the domain of computer science in the past few years. As it was presented in the World Economic Forum we are living in a digital world, with massive amounts of technology-driven change, huge innovation and significant evolution in the ways people use technology (Dutta et al., 2015). Important contributors to entrepreneurship are the high-tech sector and the information and communications technology segment (Hathaway, 2013) and every day we read about new successful IT start-up companies, about a young entrepreneur who launched a new application, about digital revolution. The main problem that arises is that entrepreneurship is not all about IT problems and solutions as media and digital world present. Also, there is a myth that men are more capable to start their own business which is unfair and discourages women to try. Thus it is possible that:

\section{Hyp. 3. There are differences between male and female students:}

Hyp 3.1. in desired career path: male students are more prone towards entrepreneurship than students of management.

Hyp 3.2. in life goals: female students are more prone towards intrinsic goals.

Women have made significant progress in entrepreneurship (Kickul et al., 2008) and it became an important source of employment for women across many countries. The number of female entrepreneurs has increased significantly in recent years but still it is more than obvious that the number of businesses owned by women is remarkably lower than the number of businesses owned by men (Guptaa et al., 2014; Pines et al., 2010).

\section{Research Methodology}

The research is conducted with the aim to explore possible relations between freshmen's life goals and their desired future career path that stands on the point that there might be a positive correlation between intrinsic goals and entrepreneurship preference. With the quantitative approach to the matter, we apply a survey method using an adjusted questionnaire based on theoretical conceptions of Deci and Ryan (2008) on targeted respondents. 


\subsection{Research Variables}

The independent variable in our research was assigned to the concept of career path preferences. Although each and every career path is different, there are some general directions. In this research we divided it into a three possible drifts: manager in large company (IV_1), manager in small family business (IV_2) and manager in his/her own business (IV_3).

Dependent variables refer to the two different life goals: intrinsic (DV1) and extrinsic (DV2). Aspirations are considered to be the specific contents of people's targets (Deci \&Ryan, 2000) and they are used to guide activities of persons toward the goals. They are explanatory concepts of, as Grouset says (Grouset et al., 2005), how people organize their lives and the types of aims to which an individual strives. Although aspirations are high level goals, i.e., life goals, they are more concrete than values, and they are proven to have more impact on behaviour (there is a higher correlation between goal and action then action and value) (Vansteenkiste et. al, 2007).

Due to the fact that the decision about the department of study might be relevant for choosing the future career direction toward or contrary to entrepreneurship, we included, as possible intervene variable, the students ' chosen department (IV_1), as well as their gender that might interfere with both career path and enrollment decision (IV_2).

\subsection{Sample}

Every year over 700 candidates enroll in two departments at the Faculty of Organizational Sciences. In the academic year 2016/17 a total of 800 students were accepted at the first year of study (including those studying as distant learning students of Informatics and technology). From the population of about 720 students at two departments (about half of them at one department), we gathered valid data from the sample of 364 freshmen (first time enrolling into the Faculty). The structure of our sample is given in Figure 1, where it can be seen that about $48 \%$ of the targeted population is included in the sample. As a matter of fact, the level of responsiveness was higher than in some other studies because data collecting was conducted before classes and almost every student that comes regularly to lectures had an opportunity to answer the questionnaire (students studying by the distant learning program were excluded). Yet, some of those questionnaires were dismissed due to the fact that some students do not take this seriously, providing the answers of no validity. The percentage of rejected questionnaires was slightly higher than $7 \%$.

As all the students are about the same age, we did not include this potential variable into consideration. Nevertheless, the gender might be of importance due to the fact that there is a slightly different gender structure in two departments.

\subsection{Research Procedure and Data Analysis}

The dependent variable of aspirations, i.e., life goal of the students of the first year of study at the Faculty of Organizational Sciences is measured by intrinsic and extrinsic aspirations scale that provided the score for the strength of those two factors indicating the direction of freshmen motivation. The score was computed based on an average obtained by summing the associated item. Independent variable was evaluated according to the category that a respondent selects, deciding among three possible options.

The statistical analysis consisted of descriptive and inference statistics (ANOVA, $t$ test and $\mathrm{C}$ coefficient). Also, we used Linear regression analysis to understand the correlation between multiple variables. Finally, we wanted to see if there was a particular profile of FOS `s freshmen future entrepreneur, so we implemented a cluster analysis.

The research is conducted during the first semester of 2016/17 academic year at the Faculty of Organizational Sciences. 


\subsection{Instruments}

We started the questionnaire with two preliminary questions considering the gender and the department of study (Information Technology and Management departments). It was followed by a very direct question about their career aspirations, offering three potential scenarios. Finally, respondents were given a set of eighteen items considering six particular goals, out of which, according to Deci and Ryan (2008), three of them referred to intrinsic (personal growth, community contribution and meaningful relations) and three of them referred to extrinsic goals (wealth, fame and self-image).

This instrument is derived from one part of the Kasser and Ryan`s scale (Kasser \& Ryan, 1996) about how important one's life goal is to a person. The original scale has two more parts and five indicators for each goal instead of three in our version. This scale measures the strength of particular goals on a five degree Likert's scale, with three items per each goal. Based on nine items, the extrinsic aspiration scale was formed, while the sum of other nine items define the intrinsic aspiration scale.

It was shown that original scale has good metric characteristics (test-retest reliability, factorial structure, construct validity and internal reliability) (Kasser et al. 1995)) and that it can be used in different cultural contexts indicating differences (Grouset et al., 2005).Comparing the original scale with the translated, shortened and adapted version, we gain similar internal reliability. While the authors report the index of reliability from Crombach 's alpha $=. .70$ to Crombach's alpha $=.84$, depending on the subscale and particular study in question (Støen Utvær et al., 2011), our scales have Crombach`s Alpha=.79; N=9 for extrinsic aspiration scale and Crombach`s Alpha $=.74 ; \mathrm{N}=9$ for intrinsic aspiration scale.

\section{Research Results}

The results given in this research consider differences between gender and department in life goal aspirations and career path plans as well as correlation between goals and potential career.

\subsection{Department, Gender and the Career Path Preferences of the Sample}

As we can see from Figure 1, there are more students of ISIT department in the sample, but there is no significant difference $(\mathrm{N}(\mathrm{ISIT})=189$ and $\mathrm{N}(\mathrm{MAN})=175)$. Also, there are more female students in sample than males in the subsample of students regardless the department. Female students make $64.84 \%$ of all respondents, where $55.08 \%$ of them are female students of Management while of $64.84 \%$ males are from Informatics.

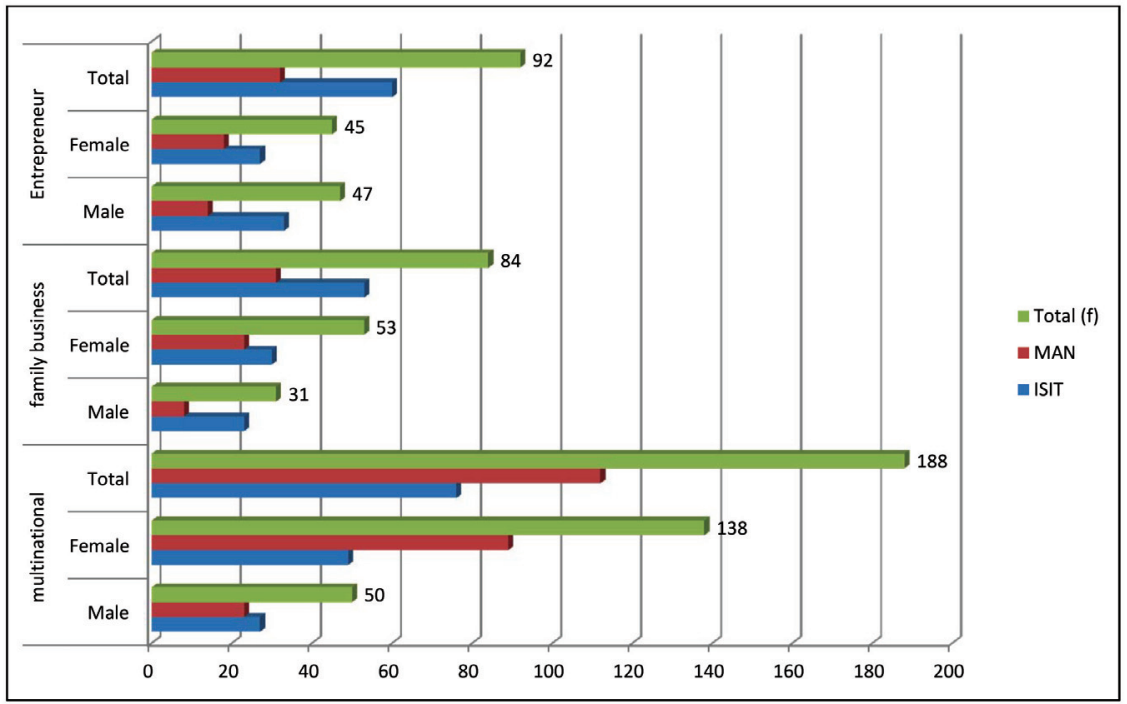

Figure 1: Career path plan of students from different departments (Informatics and Management) and gender 
The results showed that there is a difference between students of two departments according to their entrepreneurship plans $(\mathrm{C}=.23 ; \mathrm{p}<.01 ; \mathrm{N}=364)$. According to Figure 1 , students of ISIT are more prone towards it, while future managers prefer career in multinational companies. Similarly, the coefficient of contingency $(\mathrm{C}=.21 ; \mathrm{p}<.01 ; \mathrm{N}=364)$ for differences between males and females showed that multinational company was preferred by female students while entrepreneurship was favored by male students. Also, there is a correlation between gender and study option $(C=.19 ; p<.001 ; N=364)$. It implies that male candidates are more inclined towards ISIT while the number of female students enrolled at Management department in our sample is larger. It is similar to the real situation. We can conclude that entrepreneurship is more associated with male students at the department of ISIT and manager's career in multinational company is more often a choice among female management students.

\subsection{Students` Life Goals: Relation with Desired Career Path}

The first step was to search is there any relation between a desired career path and life goals. We found that, in the case of freshmen, there was no relation between their plans as to what direction they would develop their career during the studying and their life goals/aspirations (Table 1).

Table 1: Descriptive statistics (mean and standard deviations) for intrinsic and extrinsic life goals and statistical significances of difference based on chosen career path

\begin{tabular}{|c|c|c|c|c|c|c|c|c|c|c|c|c|}
\hline \multirow{2}{*}{$\begin{array}{l}\text { Career path } \\
\text { Life goals }\end{array}$} & \multicolumn{3}{|c|}{$\begin{array}{c}\text { Manager in large, } \\
\text { multinational } \\
\text { company }\end{array}$} & \multicolumn{3}{|c|}{$\begin{array}{l}\text { Manager in small } \\
\text { family business }\end{array}$} & \multicolumn{3}{|c|}{ Entrepreneur } & \multirow[b]{2}{*}{$\mathrm{F}$} & \multirow[b]{2}{*}{ Sig. } & \multirow[b]{2}{*}{ df } \\
\hline & AS & SD & $\mathrm{N}$ & AS & SD & $\mathrm{N}$ & AS & SD & $\mathrm{N}$ & & & \\
\hline Intrinsic goals & 4.32 & 0.39 & 184 & 4.37 & 0.39 & 84 & 4.33 & 0.52 & 89 & .43 & .65 & 2 \\
\hline $\begin{array}{l}\text { Extrinsic } \\
\text { goals }\end{array}$ & 3.15 & 0.65 & 182 & 2.98 & 0.57 & 80 & 3.12 & 0.55 & 88 & 2.33 & .10 & 2 \\
\hline Wealth & 4.36 & 0.5 & 184 & 4.15 & 0.55 & 80 & 4.31 & 0.62 & 91 & 4.26 & .01 & 2 \\
\hline $\begin{array}{l}\text { Personal } \\
\text { development }\end{array}$ & 4.55 & 0.47 & 186 & 4.54 & 0.5 & 84 & 4.48 & 0.63 & 90 & .54 & .58 & 2 \\
\hline Relationships & 4.73 & 0.43 & 187 & 4.79 & 0.35 & 84 & 4.73 & 0.54 & 91 & .58 & .56 & 2 \\
\hline Self-image & 2.63 & 0.87 & 188 & 2.47 & 0.82 & 84 & 2,64 & 0.8 & 89 & 1.19 & .31 & 2 \\
\hline Society & 3.69 & 0.76 & 186 & 3.8 & 0.66 & 84 & 3.75 & 0.73 & 92 & .75 & .47 & 2 \\
\hline Fame & 2.43 & 0.98 & 186 & 2.3 & 0.81 & 84 & 2.42 & 0.87 & 92 & .61 & .55 & 2 \\
\hline
\end{tabular}

The results show that intrinsic life goals are more popular among freshmen then extrinsic ones. Observing the means for each concrete goal, we can conclude that it is due to the fact that meaningful relationships are highly valued among students, while society is neglected as the aspiration, indicating a more individualistic orientation in the domain of intrinsic goals. In that context, it is not unexpected to see that the only difference between students might be seen in the domain of the life goal of acquiring wealth, where those striving toward the career in small family business show the least interest in it.

\subsection{Differences in Life Goals and Career Path based on Department and Gender}

When differences in departments are considered, students of Management have more intrinsic goals emphasizing whether their career choice is toward the multinational companies $(t=-3.5 ; p<.001 ; d f=182)$. It is interesting that students of Management have a stronger expression of goals, whether they are intrinsic or extrinsic, when they see their future career in small family business (for intrinsic: $t=-2.96 ; p<.001 ; d f=82$ and for extrinsic: $t=-2.68 ; p<.001 ; d f=78$ ). The explanation for that can be found in case that they already have some family business, so they have clear ideas of their future goals and are more aware of this.

The unexpected data was obtained for those interested in entrepreneurship career and their goals, with no differences between departments. That also can be an opportunity to create the environment for the acquisition of entrepreneurial skills unrelated to department, rather than trying to identify or select potential entrepreneurs. 


\begin{abstract}
There are no differences between male and female students and their intrinsic and extrinsic life goal orientation when they are choosing multinational companies as their future careers. The only differences are seen in a subsample of students preferring small family companies, where females are more inclined toward intrinsic goals $(\mathrm{t}=-.2,74 ; \mathrm{p}<.01 ; \mathrm{df}=82)$, thanks to personal development and social goals that are more preferred among female students.

The regression equation shows us that we could predict a career path (CP) of students by department (D) and gender $(\mathrm{G})$, with the very low probability of $8 \%(\mathrm{r} 2=, 08 ; \mathrm{p}<.01, \mathrm{df}=4)$ but not based on specific life goals, at least in the sample of freshmen. It may imply that entrepreneurs are not born but created.
\end{abstract}

$$
\mathrm{CP}=2.3-0.32 \mathrm{G}-0.32 \mathrm{D}(1)
$$

If grouped into clusters of respondents, we get two clusters with profiles of those who strive towards career in large companies are female managers (cluster 1) while the future entrepreneurs are male students who study IT (cluster 2), while centroids of life goals do not indicate differences between them.

\title{
Discussion and Conclusion
}

In this paper we have shown that in case of young people (students), the strength of specific goals (intrinsic or extrinsic) does not direct their career plans, not even on that abstract level of widely defined directions toward multinational company or entrepreneurship career. Petrovic et al. (2015) have come to the similar conclusion on the sample of more variety. That is a significant fact because it shows that entrepreneurs may not be predestined, and that educational process may influence the development of young entrepreneurs, and therefore the development of an entrepreneurial culture, innovation and the economy of the country. As it was found in the research of Omerbegovic-Bijelovic, the process of developing entrepreneurs is not only affected by educational institutions but by all stakeholders (the State and the ministries, local communities, businesses and institutions, family businesses, media and other stakeholders) who can design programmess to bring the young generations into the entrepreneurial sphere (Omerbegovic-Bijelovic et al., 2016).

Based solemnly on life goals, even with the information of gender and department, it is not possible to be sure which freshmen would be prone to entrepreneurship career. Is it rather a question of proper education and developed skills, or some other personal factors that create a potential entrepreneurship? It gives us a wide range of potential individual variables to explore and consider, as well as the opportunity to define an adequate educational environment for future career to grow in the desired direction. We expect that future research might identify personal as well as situational factors that enhance entrepreneurship career decision among business students.

\section{Acknowledgements}

Parts of this paper have been presented at the XV International Symposium SYMORG 2016 "Reshaping the future through sustainable business development and entrepreneurship", Zlatibor, Serbia, 2016.

\section{REFERENCES}

[1] Bateman, T. S., O'Neill, H., \&Kenworthy-U'Ren, A. (2002). A hierarchical taxonomy of top managers' goals. Journal of Applied Psychology, 87(06), 1134-1148. DOI: 10.1037/0021-9010.87.6.1134

[2] Culbertson, S., Smith, M., \&Leiva, P. (2011). Enhancing Entrepreneurship: The Role of Goal Orientation and Self-Efficacy. Journal of Career Assessment, 19(2), 115-129. DOI: 10.1177/1069072710385543

[3] Deci, E. L., \&Ryan, R. M. (2000). The "what" and "why" of goal pursuits: Human needs and the self-determination of behavior. Psychological Inquiry , 11(4), 227-268. DOI: 10.1207/S15327965PLI1104_01

[4] Deci, E. L., \&Ryan, R. M. (2008). Self-determination theory: A macrotheory of human motivation, development, and health. Canadian Psychology/Psychologiecanadienne, 49(3), 182-185. DOI: $10.1037 / \mathrm{a} 0012801$

[5] Dutta S., Geiger, T., \&Lanvin, B. (2015). The Global Information Technology Report. ICTs for Inclusive Growth. World Economic Forum and INSEAD.

[6] Guptaa, V. K., Goktanb A.B., \& Gunay G. (2014). Gender differences in evaluation of new business opportunity: A stereotype threat perspective. Journal of Business Venturing, 29(2), 273-288. DOI: 10.1016/j.jbusvent.2013.02.002 
[7] Grouset, F. M., Ahuvia, A., Youngmee, K., Ryan, R. M., Schmuck, P., \& Kasser, T. (2005). The Structure of Goal Contents Across 15 Cultures. Journal of Personality and Social Psychology, 89 (5), 800-816. DOI: $10.1037 / 0022-3514.89 .5 .800$

[8] Hathaway, I. (2013). Kauffman Foundation Research Series: Firm Formation and Economic Growth. Tech Starts: High-Technology Business Formation and Job Creation in the United States. Ewing Marion Kauffman Foundation

[9] Kasser, T., \& Ryan, R. M. (1996). Further examining the American dream: Differential correlates of intrinsic and extrinsic goals. Personality and Social Psychology Bulletin, 22(3), 280-287. DOI: $10.1177 / 0146167296223006$

[10] Kasser, T., Ryan, R. M., Zax, M., \& Sameroff, A. J. (1995). The relations of maternal and social environments to late adolescents' materialistic and prosocial values. Developmental Psychology, $31(6)$, 907-914. DOI: 10.1037/0012-1649.31.6.907

[11] Kasser,T., \& Ryan,R. M. (2001). Be careful what you wish for: Optimal functioning and the relative attainment of intrinsic and extrinsic goals. In P. Schmuck \& K. M. Sheldon (Eds.), Life goals and wellbeing: Towards a positive psychology of human striving, 116-131.

[12] Kickul, J., Wilson, F., Marlino, D., \& Barbosa D. S. (2008). Are misalignments of perceptions and self efficacy causing gender gaps in entrepreneurial intentions among our nation's teens? Journal of Small Business and Enterprise Development, 15 (2), 321 - 335. DOI: 10.1108/14626000810871709

[13] Locke E. A., \& Latham P. G. (2006). New Directions in Goal-Setting Theory. Association for Psychological Science, 15(5), 265-268. DOI: 10.1111/j.1467-8721.2006.00449.x

[14] Malach-Pines, A., Sadeh, A., Dvir, D., \& Yafe-Yanai, O. (2002). Entrepreneurs and managers: Similar yet different. International Journal of Organizational Analysis, 10(2), 172-190. DOI: 10.1108/eb028949

[15] Marques, L., \&Albuquerque, C. (2012). Entrepreneurship education and the development of young people life competencies and skills. ACRN Journal of Entrepreneurship Perspectives,1(2), 55-68.

[16] Matlay, H., (2005). Researching entrepreneurship and education: Part 1: What is entrepreneurship and why does it matter? Education and Training, 47 (8), 665-667.

[17] Milinkovic, I., Kovacevic, I., \& Mihailovic, D. (2016). The main motivating factors for someone to take up entrepreneurship. Proceedings of the XIV international symposium SymOrg 2016: Reshaping the Future through Sustainable Business Development and Entrepreneurship. Belgrade. Faculty of organizational sciences.

[18] Omerbegovic-Bijelovic, J., Mirkovic, P., \& Rakicevic, Z. (2016). Arguments for designing programmes for encouraging the youth in Serbia towards entrepreneurship. Proceedings of the XIV international symposium Symorg 2016: Reshaping the Future through Sustainable Business Development and Entrepreneurship. Belgrade. Faculty of organizational sciences.

[19] Petrovic, N., Cabarkapa, M., \& Kuzmanovic, B. (2015). Vrednosna ocekivanja učenika gimnazija pri izboru zanimanja. Zbornik radova Filozofskog fakulteta u Pristini 45(4),3-24.

[20] Pines A. M., Lerner M., \& Schwart D. (2010). Gender differences in entrepreneurship. Equality, diversity and inclusion in times of global crisis. Equality, Diversity and Inclusion: An International Journal, 29(2),186-198. DOI: 10.1108/02610151011024493

[21] Sheldon, M., Ryan, R., \& Deci, E. (2004). The Independent Effects of Goal Contents and Motives on WellBeing: It's Both What You Pursue and Why You Pursue It. Personality and Social Psychology Bulletin. Society for Personality and Social Psychology. 30 (4), 475-486DOI: 10.1177/0146167203261883

[22] Støen Utvær. B.K., Hammervold, R., \& Haugan, G. (2014). Aspiration Index in vocational students - dimensionality, reliability, and construct validity. Education Inquiry, 5(3), 359-383. DOI: 10.3402/edui.v5.24612

[23] Vansteenkiste, M., Neyrinck, B., Niemiec, C. P., Soenens, B., De Witte, H., \& Van den Broeck, A. (2007). On the relations among work value orientations, psychological need satisfaction and job outcomes: $A$ self-determination theory approach. Journal of Occupational and Organizational Psychology, 80(2), 251-277. DOI: 10.1348/096317906X111024 


\section{$1 / 1 / 1 / 1 / 1 / 1 / 1 / 1 / 1 / 1 / 1 / 1 / 1 / 1 / 1 / 1 /$ abouthenenthor}

\section{Ivana Milinković \\ University of Belgrade, Faculty of Organizational Sciences, Serbia milinkovic.ivana@fon.bg.ac.rs}

Ivana Milinković is a teaching associate at the Faculty of Organizational Sciences, University of Belgrade, Human Resource Management Department. She graduated at the Faculty of Organizational Sciences, and now she is a student of master studies at the same Faculty, in the study group Human Resource Management. Ivana is the author and co-author of a few papers and conference proceedings.

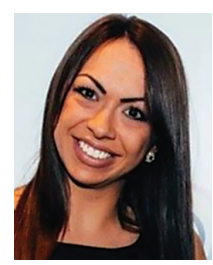

\section{Ivana Kovačević}

University of Belgrade, Faculty of Organizational Sciences,Serbia kivana@fon.bg.ac.rs

Ivana Kovačević is an assistant professor at the Faculty of Organizational Sciences, University of Belgrade, Human Resource Management Department. She graduated in Psychology at the Faculty of Philosophy, Belgrade University, where she obtained an $\mathrm{PhD}$ in the domain of Work Psychology. She is the author and co-author of numerous papers and conference proceedings, some of them published in leading scientific journals.

\section{Dobrivoje Mihailović University of Belgrade, Faculty of Organizational Sciences, Serbia mihailovic.dobrivoje@fon.bg.ac.rs}

Dobrivoje Mihailović is full professor at Faculty of Organizational Sciences, University of Belgrade, Human Resource Management Department, where he teaches the following courses: Psychology, Business Psychology, Team Work, Human Relations in the

Organization, Leadership and Methodology. He is the author and co-author of numerous monographs and text books in the area of organizational psychology and methodology. He published over 100 articles and papers in national and international scientific journals and professional magazines, some of them presented at relevant conferences. He participated in the realization of about 20 strategic scientific and research projects.
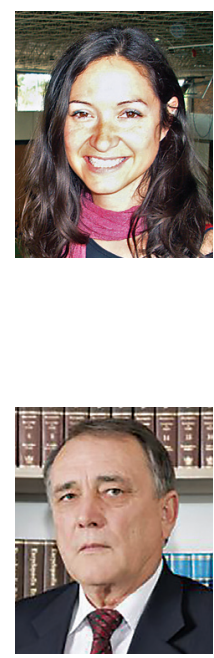


\section{dIIIIIIIIIIIIIIIIIIIIIIIIIIII Management Journal of Sustainable Business and Management Solutions in Emerging Economies}

